\title{
Students' critical thinking level: examining Wimba Voice Board and text online discussions
}

\author{
Biao Bin Pang $\cdot$ Khe Foon Hew
}

Received: 14 October 2013/Revised: 28 February 2014/ Accepted: 2 March 2014/

Published online: 2 April 2014

(C) Beijing Normal University and Springer-Verlag Berlin Heidelberg 2014

\begin{abstract}
In this study, we examined the use of Wimba Voice Board and a textbased online discussion in supporting students' critical thinking. Specifically, we addressed the following question, "Is there any significant difference in the level of students' critical thinking in asynchronous audio compared to text discussions?" Two undergraduate classes participated in the study. Class A $(n=23)$ was randomly assigned to use the Wimba Voice available at Blackboard, while Class B $(n=18)$ used a text discussion forum, also at Blackboard. Both classes were asked to discuss on a similar open-ended topic with the same duration of time. We investigated if there was any significant difference in the levels of critical thinking between these two classes using Greenlaw and Deloach's (2003) taxonomy of critical thinking. Results of a Pearson $\chi^{2}$ test statistics suggested a significant relationship between the levels of critical thinking and the type of asynchronous online discussion. Students produced more than expected higher critical thinking levels during asynchronous audio discussion. On the other hand, students exhibited more than expected lower critical thinking in asynchronous text discussion.
\end{abstract}

Keywords Critical thinking - Asynchronous online discussion · Audio discussion - Text discussion

\section{Introduction}

In recent years, the use of online learning is increasingly being utilized by many educators around the world. Allen and Seaman (2013), for example, reported that

\section{B. B. Pang}

Ministry of Education, Singapore, Singapore

K. F. Hew ( $\square)$

Faculty of Education, The University of Hong Kong, Pokfulam, Hong Kong e-mail: kfhew@hku.hk 
there were over 6.1 million students who took at least one online course during the fall 2011 term; this was an increase of 560,000 students over the previous year. In addition, as many as $65 \%$ of higher education institutes now say that online learning is a critical part of their long-term strategy (Allen and Seaman 2013).

Although the trend toward online learning is expected to increase, it is important to note that successful online learning does not occur automatically just because an online component is added to it (Cheung and Hew 2011). Opportunities for students to interact with one another, and with the instructor have been identified as one of the important factors that could maximize success in an online learning environment (Dziuban et al. 2004). Indeed several scholars have identified online discussion as being one of the activities that students found most beneficial to their learning because it enables students to ask questions, exchange opinions, share multiple perspectives, and clarify doubts (Dunlap 2005; Ertmer et al. 2007; Richardson and Swan 2003).

One of the most common means for students to discuss with one another online is through text-input asynchronous discussion forums which allow students to communicate at their own pace (Kalelioglu and Gulbahar 2014; Lee 2013; Loncar et al. 2014; Thomas 2013). This, however, may not work well for some participants. For example, participants may find it difficult to explain complex concepts in words, while others complain of being misunderstood due to the absence of verbal cues (Hew and Hara 2007). Still others find it very burdensome to read and respond because they have weak reading or writing abilities (Bowe 2002). The recent emergence of technological tools (e.g., Wimba Voice Board, Voice Thread) that support voice input has provided a possible alternative for students to participate in a discussion. So far there has been little research into the use of asynchronous audio discussion in learning and teaching.

While the use of audio in online learning is not new, many of the audio technologies used such as radio, audiocassettes, compact disks, and more recently podcasts suffer from a lack of interactivity among students or between students and the instructor (Junor 1992), because these technologies are commonly used to transmit information one-way to students. The use of asynchronous audio discussion, on the other hand, provides a means for multiple-way interactions such as students communicating with other students, or with the instructor.

In this study, we examined the use of a Wimba Voice Board to support asynchronous online audio discussion as it was available in Blackboard, a course management system that our university adopted. The Wimba Voice Board (Fig. 1) allows participants to speak into a microphone and record it as an audio clip on a computer.

The audio clips (i.e., online messages) are then archived and the message structure is easily visible with threaded message trees. Participants also have the option of typing a short description to be appended to the audio clip. Participants can easily click on any audio clips, hear the online message, and orally reply to the message. Discussion posts can also be exported and downloaded in various audio formats such as MP3, and WAV should the participants desire to keep a permanent record of the asynchronous audio discussions. 


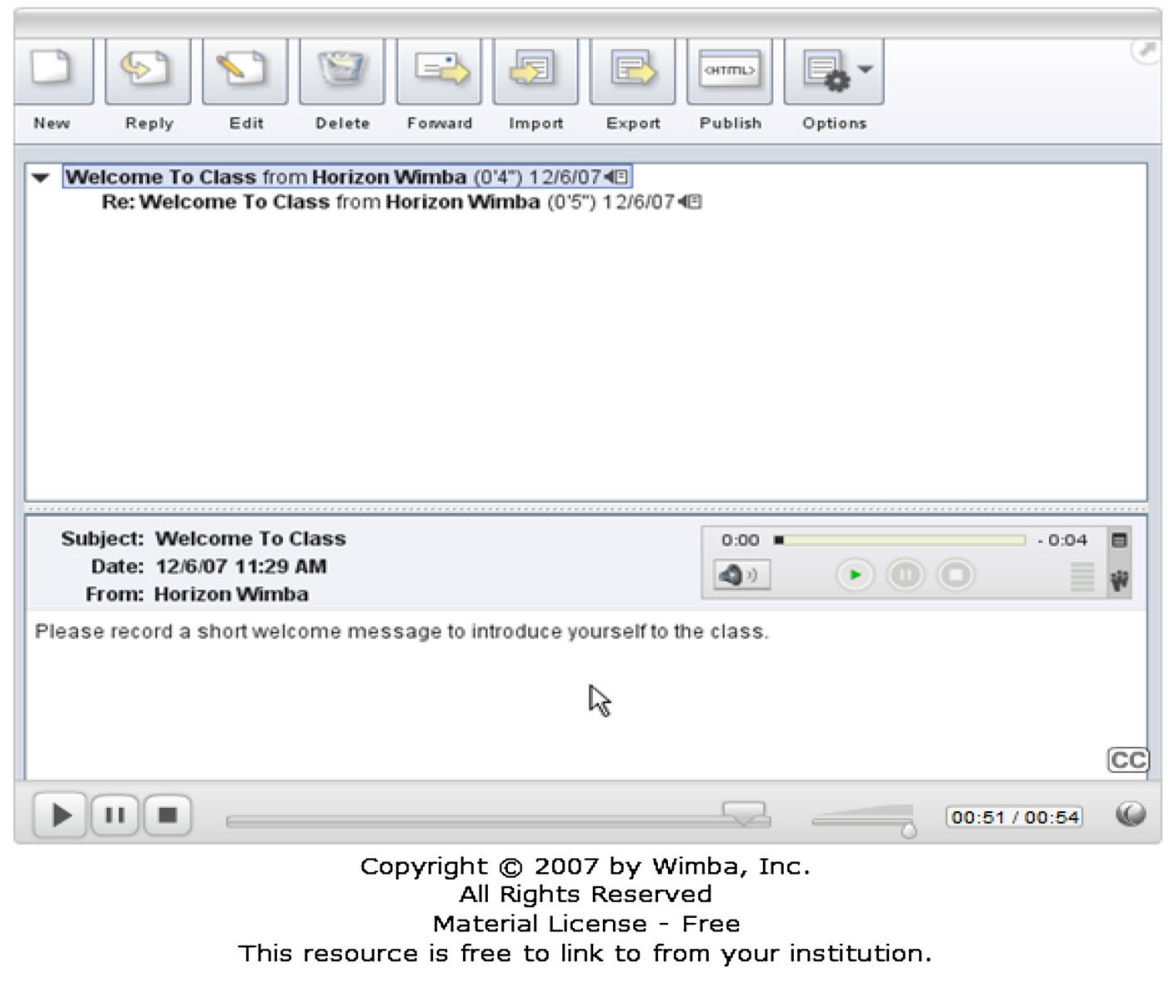

Fig. 1 Screen shot of a Wimba Voice Board (http://www.wimba.com/assets/videos/VoiceBoard/ VoiceBoard.html)

The rest of the article is organized as follows. First, in the literature review section, we briefly describe and summarize some of the past available research on asynchronous audio discussion. We then describe the methodology of the study, followed by the findings, discussion, and conclusion of the study.

\section{Literature review}

Asynchronous online discussion has become a common means of facilitating interactions among students beyond their physical classrooms. However, most previous studies have largely examined asynchronous text discussions. Research on asynchronous audio discussions is relatively scarce.

Scholars such as Akasha (2011), Brunvand and Byrd (2011), and Mandernach and Taylor (2011), among others have suggested that using asynchronous audio discussion can increase student engagement and motivation during the learning process. Such claims and suggestions, however, have often been made not based on empirical findings. The actual number of empirical studies on asynchronous audio discussion is still relatively small, compared to studies on asynchronous text 
Table 1 Summary of previous empirical studies on asynchronous audio discussion

\begin{tabular}{|c|c|c|c|c|}
\hline Author & Purpose & Design & Context & Data sources \\
\hline Chang (2010) & $\begin{array}{l}\text { Determine students' } \\
\text { acceptability of } \\
\text { asynchronous online } \\
\text { discussions on mobile } \\
\text { devices }\end{array}$ & $\begin{array}{l}\text { Case } \\
\text { study }\end{array}$ & $\begin{array}{l}32 \text { information } \\
\text { management students }\end{array}$ & $\begin{array}{l}\text { Questionnaire, } \\
\text { interview }\end{array}$ \\
\hline $\begin{array}{l}\text { Cho and } \\
\text { Carey } \\
(2001)\end{array}$ & $\begin{array}{l}\text { Explore the use of Wimba } \\
\text { Voice Board on Korean } \\
\text { oral fluency }\end{array}$ & $\begin{array}{l}\text { Case } \\
\text { study }\end{array}$ & $\begin{array}{l}7 \text { students in a Korean } \\
\text { language beginner's } \\
\text { course }\end{array}$ & Not mentioned \\
\hline $\begin{array}{l}\text { Gleason and } \\
\text { Suvorov } \\
(2011)\end{array}$ & $\begin{array}{l}\text { Examine students' } \\
\text { perception of using } \\
\text { asynchronous voice } \\
\text { discussion for developing } \\
\text { their second language oral } \\
\text { proficiency }\end{array}$ & $\begin{array}{l}\text { Case } \\
\text { study }\end{array}$ & $\begin{array}{l}10 \text { non-native English } \\
\text { students }\end{array}$ & $\begin{array}{l}\text { Questionnaire, } \\
\text { interview }\end{array}$ \\
\hline $\begin{array}{l}\text { Hew and } \\
\text { Cheung } \\
(2013)\end{array}$ & $\begin{array}{l}\text { Examine students' } \\
\text { perception of using } \\
\text { asynchronous voice versus } \\
\text { text }\end{array}$ & $\begin{array}{l}2 \text { case } \\
\text { studies }\end{array}$ & $\begin{array}{l}\text { Study } 1-41 \text { graduate } \\
\text { students majoring in } \\
\text { instructional technology, } \\
\text { Study II-42 } \\
\text { undergraduates majoring } \\
\text { in education }\end{array}$ & $\begin{array}{l}\text { Student } \\
\text { reflection }\end{array}$ \\
\hline $\begin{array}{l}\text { Marriott and } \\
\text { Hiscock } \\
(2002)\end{array}$ & $\begin{array}{l}\text { Determine the viability of } \\
\text { using asynchronous voice } \\
\text { discussion to stimulate } \\
\text { discussion and student } \\
\text { understanding of weekly } \\
\text { readings }\end{array}$ & $\begin{array}{l}\text { Case } \\
\text { study }\end{array}$ & $\begin{array}{l}154 \text { in year 2001, } 124 \text { in } \\
\text { year } 2002 \\
\text { communication course } \\
\text { students }\end{array}$ & $\begin{array}{l}\text { Server log, } \\
\text { questionnaire }\end{array}$ \\
\hline $\begin{array}{l}\text { McCormack } \\
\text { (2010) }\end{array}$ & $\begin{array}{l}\text { Explore students' use of } \\
\text { Voice Thread for } \\
\text { reviewing and reflection on } \\
\text { shared learning } \\
\text { experiences }\end{array}$ & $\begin{array}{l}\text { Case } \\
\text { study }\end{array}$ & 25 student teachers & Interview \\
\hline $\begin{array}{l}\text { McIntosh } \\
\text { et al. (2003) }\end{array}$ & $\begin{array}{l}\text { Explore students' experience } \\
\text { of using Wimba Voice } \\
\text { Board }\end{array}$ & $\begin{array}{l}\text { Case } \\
\text { study }\end{array}$ & $\begin{array}{l}41 \text { international students } \\
\text { learning English }\end{array}$ & $\begin{array}{l}\text { Questionnaire, } \\
\text { observation, } \\
\text { server log }\end{array}$ \\
\hline $\begin{array}{l}\text { Nowakowski } \\
\text { and Frazier } \\
(2009)\end{array}$ & $\begin{array}{l}\text { Explore the use of Wimba } \\
\text { for teaching basic Spanish } \\
\text { vocabulary }\end{array}$ & $\begin{array}{l}\text { Case } \\
\text { study }\end{array}$ & $\begin{array}{l}41 \text { students enrolled in } \\
\text { Spanish for eye care } \\
\text { course }\end{array}$ & $\begin{array}{l}\text { Questionnaire, } \\
\text { server log }\end{array}$ \\
\hline Poza (2011) & $\begin{array}{l}\text { Investigate the influence of } \\
\text { asynchronous voice } \\
\text { discussion on second } \\
\text { language learners' } \\
\text { speaking anxiety }\end{array}$ & $\begin{array}{l}\text { Case } \\
\text { study }\end{array}$ & $\begin{array}{l}35 \text { students majoring in } \\
\text { Spanish }\end{array}$ & $\begin{array}{l}\text { Questionnaire, } \\
\text { interview }\end{array}$ \\
\hline $\begin{array}{l}\text { Yaneske and } \\
\text { Oates } \\
(2010)\end{array}$ & $\begin{array}{l}\text { Evaluate the use of a Wimba } \\
\text { Voice Board to support } \\
\text { asynchronous audio } \\
\text { discussion }\end{array}$ & $\begin{array}{l}\text { Case } \\
\text { study }\end{array}$ & $\begin{array}{l}11 \text { graduate students in a } \\
\text { MA course entitled } \\
\text { "Language Learning and } \\
\text { Teaching with ICT" }\end{array}$ & $\begin{array}{l}\text { Questionnaire, } \\
\text { interview }\end{array}$ \\
\hline
\end{tabular}

discussion. Table 1 summarizes some of the available empirical-based papers that used asynchronous audio online discussions. The dearth of data on asynchronous audio discussion speaks to the need for research in the area. 
Overall, a review of the literature suggested that asynchronous audio discussion has the following advantages: (a) it provides a more natural and hence easier way to present ideas and respond to others (Marriott and Hiscock 2002), (b) it provides participants with a richer means of communication (e.g., verbal cues and emotional context) which helps enhance the meaning of a message posted (Marriott and Hiscock 2002; Yaneske and Oates 2010), (c) it helps participants (especially language learners) to practise speaking, listening, and do self-diagnosis of pronunciation errors (Gleason and Suvorov 2011; McIntosh et al. 2003; Yaneske and Oates 2010), (d) it can help increase social presence because the ability to hear other people's voices helped foster a more personal connection to them (Yaneske and Oates 2010), and (e) it is relatively easy and user-friendly to use without the need for additional software or complex installation (Gleason and Suvorov 2011; McCormack 2010; McIntosh et al. 2003).

Some of the challenges of using asynchronous audio discussion, on the other hand, include the following: (a) it is difficult to correct errors because participants were unable to edit the recordings once they were posted (Gleason and Suvorov 2011; Marriott and Hiscock 2002), (b) some participants were embarrassed to record their voices and let others hear how they sounded (Marriott and Hiscock 2002; McIntosh et al. 2003; Yaneske and Oates 2010), and (c) an inability to skim audio quickly forces participants to replay the message repeatedly should they want to hear something again or could not hear it properly (Yaneske and Oates 2010).

There are two major limitations concerning the existing research on asynchronous audio discussion. First, all the studies were primarily limited to an examination of students' affective outcome such as their feelings or attitudes toward using asynchronous audio discussion. There is a need to investigate whether the use of asynchronous audio discussion could affect other students' outcome such as their level of critical thinking. Second, a majority of previous studies focused on disciplines such as language learning (e.g., learning Spanish or English), or communications studies (e.g., Cho and Carey 2001; Gleason and Suvorov 2011; Marriott and Hiscock 2002; McIntosh et al. 2003; Poza 2011; Yaneske and Oates 2010). The examination of asynchronous audio discussion in these studies was mainly limited to how it could improve students' oral and listening skills, and whether it was easy and user-friendly to use (e.g., Cho and Carey 2001; Gleason and Suvorov 2011; McIntosh et al. 2003).

\section{Research questions}

The current study attempts to overcome the aforementioned limitations. This study is situated in a teacher education context and attempts to measure students' critical thinking level in relation to asynchronous audio discussion usage. More specifically, the following research question was explored in this study:

Is there any significant difference in the level of students' critical thinking in asynchronous audio compared to text discussions? More detail explanations of critical thinking levels are provided in the "Method" Section. 


\section{Method}

\section{Participants}

Forty-one students participated in this study. These 41 students came from two classes, class A and class B, henceforth referred to as Group A and Group B, respectively. Group A consisted of 23 students, 8 male and 15 female. Group B consisted of 18 students, 5 male and 13 female. These students were pursuing an undergraduate degree in education. Both groups were taught by the same instructor for semester. In both groups, students used the same course materials, and did the same asynchronous discussion activities.

\section{Procedure and data analysis}

One of the groups (Group A) was randomly assigned to use the Wimba Voice Board while Group B used a text discussion forum. Both the Voice Board and the text discussion forum were available in BlackBoard. Specifically, students from both groups were asked to discuss on the topic, "Organ Trading," i.e., "Recently, there was a spate of discussion about organ trading in Singapore. Do you think it's okay for people to buy or sell organs? Justify your viewpoints." No teacher's intervention or facilitation was present. The students were given the liberty to create their own threads or to respond to other students' threads.

"Organ Trading" topic was selected due to its nature as a controversy topic which enables different individuals to hold different views. In other words, this topic was an open-ended topic with more than one possible perspective, and no obvious right or wrong answers. Using open-ended topics or questions has been found to encourage student contribution and stimulate students' interactions (Dysthe 2002; Hew and Cheung 2012, 2013; Poscente and Fahy 2003). This topic was much debated upon after a Singapore Tycoon Tang Wee Sung was reported paying a broker $\$ 220,000$ to secure a healthy kidney from an Indonesian man. Various views emerged to support or against the act. For example, several people suggested legalizing the payment of kidney donors in the local newspaper. On the other hand, several prominent doctors were against this idea of legalizing payment and the Singapore Medical Association has also come out against such payment. There is hence, a good ground for active discussion for the students on this topic.

To answer the research question, "Is there any significant difference in the level of students' critical thinking in asynchronous voice versus text discussions?", we first coded all the students online posts using Greenlaw and Deloach's (2003) taxonomy of critical thinking. We used Greenlaw and Deloach (2003) Taxonomy of Critical Thinking (Table 1) to evaluate the level of critical thinking of the participants in both the Wimba Voice Board and text discussion forum. This taxonomy provides a greater analysis of the different levels of critical thinking, unlike that of other scholars such as Cheung and Hew (2006), or Henri (1992) that merely describes a dichotomy of surface or shallow versus in-depth level of critical thinking. The unit of analysis was the thematic unit. This selection was consistent 
with Merriam's (2001) recommendation that communication of meaning be the main focus.

Greenlaw and Deloach's particular framework (Table 2) assesses the quality of student critical thinking in terms of seven different levels of information processing: (a) level 0-off-topic, (b) level 1-unilateral descriptions, (c) level 2-simplistic argument, (d) level 3-basic analysis, (e) level 4-theoretical inference, (f) level 5-empirical inference, and (g) level 6-merging values with analysis.

In order to estimate the consistency of the analysis, an independent observer coded all the messages posted by both groups. The percentage of agreement of the coding was $84.48 \%$ for group A (asynchronous text discussion), and $89.13 \%$ for group B (asynchronous audio discussion). Since there is more than $80 \%$ accuracy in both groups' analyses, it can be assumed that the coding was fairly accurate. After the coding had been completed, a Pearson $\chi^{2}$ test of relationship was computed to examine if there was any significant relationship between the levels of critical thinking and the type of asynchronous online discussions.

\section{Results}

The results of the critical thinking analyses of both groups are summarized in Table 3.

As seen from Table 3, both group A and group B have the same number of critical thinking points of 106. However, group A had a total of 58 posts while group B had 46 posts. Since the total number of posts was different for each group, it was not a fair comparison for the total number of critical thinking points. As such, the average was taken, which was the total number of critical thinking points divided by the total number of posts of the particular group to achieve the average critical thinking points per post. Group B's average critical thinking point per post was computed to be 2.30, whereas group A's average critical thinking points was 1.83. We can therefore say that on average, the critical thinking level as exhibited by group B (asynchronous audio discussion) was higher than that of group A. Table 4 shows the different levels of critical thinking and the frequency of its occurrences for both groups. The results of a Pearson $\chi^{2}$ test of statistics confirmed a significant relationship between the levels of critical thinking and the type of asynchronous online discussions: $\chi^{2}(2, N=104)=14.578, p=0.001$, Cramer's $V=0.374$. The data in Table 5 suggested that students produced more than expected higher critical thinking level during asynchronous audio discussion. On the other hand, students exhibited more than expected lower critical thinking in asynchronous text discussion.

\section{Conclusion}

In this study, we investigated the use of asynchronous audio discussion. We found no discussion posts coded as off-task or off-topic, which implies that the students in both asynchronous audio and text discussion groups focused very much on content, 
Table 2 Critical thinking framework (adapted from Greenlaw and Deloach 2003)

\begin{tabular}{l} 
Level (points) \\
\hline Level $0(0)$ \\
Level 1: unilateral \\
descriptions (1)
\end{tabular}

Level 2: simplistic alternatives/ argument (2)

Level 3: basic analysis (3)

Level 4: theoretical inference (4)

Level 5: empirical inference (5)

\section{Description}

Off-the subject or otherwise unscorable

Students paraphrase information, they repeat and restate the question

Define terms

Simply repeat information

Simple "good" or "'bad" statements

Add little or nothing new to the issue or question

Present a source

They take a side, they do not explore other alternatives, they make unsupported assertions, they make simplistic arguments An assertion, without evidence, often in the form of a question that modestly advances thinking; often synonymous with getting the discussion back on track

Challenge an assertion but without evidence

Facts (beyond defining terms) relevant to the discussion but no argument, per se

Simple explanations, e.g., giving an example

Cite simple rules, "laws" as proof

Do not address conflicts with opposing views or do not explore them

They make a serious attempt to analyse an argument or competing arguments and evaluate it/them with evidence

Appeal to a recognized (appropriate) authority

Casual observation, anecdotal, datum (vs. data)

Assertions with explicit evidence offered: or a reasoned challenge of another's assertion but without a clear logical framework

A singular, Socratic-style question

Often list numerous factors as evidence

They employ the use of theory to make a cohesive argument

Logical statements based on the discipline's accepted model/ school(s) of thought

Identify assumptions

Challenge a key assumption of another's theory

A series of logical, Socratic-style questions

Add to the level of sophistication by introducing empirical evidence to strengthen their theoretical argument

Use appropriate, historical data lo "test" the validity of an argument

Use data to reach a clear conclusion or to choose between alternative theories

Require at least an implicit logical framework

Challenge the validity of another's empirical measure/ evidence 
Table 2 continued

\begin{tabular}{ll}
\hline Level (points) & Description \\
\hline $\begin{array}{l}\text { Level 6: merging } \\
\text { values with analysis } \\
\text { (6) }\end{array}$ & $\begin{array}{l}\text { They are able to move beyond objective analysis to incorporate } \\
\text { subjective interests }\end{array}$ \\
& They may argue that although there is (positive) evidence to \\
& validate the use of a particular policy, there are other \\
(normative) consequences that must be considered & They may select a particular policy on some normative basis, \\
from several which have positive evidence to support them
\end{tabular}

rather than on technical or social topics. It could be that the nature of asynchronous audio or text as a discussion tool imposes a level of formality that enables students to focus on content. It might also be that both discussion tools (Wimba Voice Board and the text discussion forum available at Blackboard) were user-friendly, thereby minimizing the technology problems that might have been encountered by students. It could also simply be that students did not really feel the need to talk about social issues through a computer-mediated format because they were taking the course in a blended setting, since there are enough opportunities to talk about such issues during face-to-face class time.

Overall, the results of the current study showed that asynchronous audio discussions were more likely to yield level 3 critical thinking occurrences, while text discussions were more likely to foster levels 1 and 2 critical thinking. Why is this so?

In an attempt to uncover the possible reason for this, we asked the students in group B to write their reflections about the possible benefits of using asynchronous audio discussion. Apparently, the use of asynchronous audio discussion can help students understand their peer's viewpoints better due to the presence of intonation and the expression of emotions. For example, Student A explained in her reflection, "We are able to interpret not only the ideas presented but how it is presented such as the intonations that may give us a clearer picture of the message posted." Another student wrote, "In my opinion, through voice-based discussions, participants will be able to portray their feelings through the tones of their voice. This will enable those who listen to them to better understand what they are trying to say about a certain issue."

Recall that level 3 critical thinking typically requires a student to make a serious attempt to analyse an argument or competing arguments and evaluate them with evidence. We suggest that the presence of intonation and the expression of emotions afforded by asynchronous audio discussion could help foster level 3 critical thinking because they add clarity and meaning to an individual's message (Durbridge 1984). This enables other participants to have a clearer picture of what the entire discussion is about. A clearer understanding of the discussion helps participants to better analyse arguments, and construct more thoughtful or in-depth responses to the issues at hand. 
Table 3 Total critical points for each group

\begin{tabular}{lll}
\hline & $\begin{array}{l}\text { Asynchronous text } \\
\text { discussion (Group A) }\end{array}$ & $\begin{array}{l}\text { Asynchronous audio } \\
\text { discussion (Group B) }\end{array}$ \\
\hline Total critical thinking (CT) points & 106 & 106 \\
Total number of posts & 58 & 46 \\
Critical thinking (CT) point per post (mean) & 1.83 & 2.30 \\
\hline
\end{tabular}

Table 4 Critical thinking levels exhibited by both groups

\begin{tabular}{lllllllll}
\hline Level of critical thinking & $\begin{array}{l}\text { Level } \\
0\end{array}$ & $\begin{array}{l}\text { Level } \\
1\end{array}$ & $\begin{array}{l}\text { Level } \\
2\end{array}$ & $\begin{array}{l}\text { Level } \\
\text { Level }\end{array}$ & $\begin{array}{l}\text { Level } \\
5\end{array}$ & $\begin{array}{l}\text { Level } \\
6\end{array}$ & $\begin{array}{l}\text { Total no. } \\
\text { of Posts }\end{array}$ \\
\hline $\begin{array}{l}\text { Number of posts } \\
\text { (asynchronous text } \\
\text { discussion) }\end{array}$ & 0 & 16 & 36 & 6 & 0 & 0 & 0 & 58 \\
$\begin{array}{l}\text { Number of posts } \\
\text { (asynchronous audio } \\
\text { discussion) }\end{array}$ & 0 & 3 & 26 & 17 & 0 & 0 & 0 & 46 \\
\hline
\end{tabular}

Table 5 More detailed analysis of critical thinking levels

\begin{tabular}{lllll}
\hline & \multicolumn{2}{l}{ No. of posts exhibiting the level of critical thinking } & Total \\
\cline { 2 - 5 } & Level 1 & Level 2 & Level 3 & \\
\hline Audio-input AOD & & & 17 & 46 \\
Count & 3 & 26 & 10.2 & 46.0 \\
Expected & 8.4 & 27.4 & 37.0 & 100.0 \\
$\%$ of total & 6.5 & 56.5 & 2.1 & - \\
Std. residual & -1.9 & -0.3 & & 58 \\
Text-input AOD & & & 6 & 58 \\
Count & 16 & 36 & 6 & 100.0 \\
Expected & 10.6 & 34.6 & 10.3 & - \\
$\%$ of total & 27.6 & 62.1 & -1.9 & \\
Std. residual & 1.7 & 0.2 & & \\
\hline
\end{tabular}

\section{Limitations and future research}

The study was conducted with only two groups of participants, i.e., Group A with 23 participants and group B with 18 participants. We were unable to randomly assign each student to either group as the groups were already intact when the semester began. As the participants were different in group A and group B, one group of students may be more vocal than the other group.

Hence, the results of this study might not be generalizable. As the current study samples consisted of Asian students majoring in education at a large Asian-Pacific 
University, it would be useful to replicate this study in other cultures to see if the reported findings still apply. Also, these samples are just a small proportion of the entire student population and should not be seen as representative of the whole student population.

Despite the limitations, it is believed that this study still served its purpose to enable other educators and researchers have a glimpse into the critical thinking level as exhibited by the students participating in different types of asynchronous online discussions. Future studies should be conducted using a larger cohort of students from various disciplines.

The study could also be conducted for a prolonged period of time, possibly stretching over 1 year of study, i.e., two semesters, and with the same group of participants involving in different types of asynchronous online discussion over the two semesters. The group of participants can stay constant while the topic for discussion can varies. Doing so could help the researchers better understand the impact or effect of different discussion topics on critical thinking levels across various types of asynchronous online discussion environments. It could also help the researchers to examine students' attitudes toward asynchronous audio discussion over a period of time, after novelty effects fade off.

Finally, future research could examine the use of asynchronous audio discussion in supporting other student outcomes such as social construction of knowledge and problem solving process (Hew et al. 2004). It may also be worthwhile to examine the use of asynchronous audio discussion on small screen mobile devices. Recently, some course management system providers such as Blackboard ${ }^{\mathrm{TM}}$ have announced the launch of Blackboard Mobile ${ }^{\mathrm{TM}}$ Learn which allows students to participate in threaded online discussions (Maurer 2011) on a variety of mobile devices including Android devices, Blackberry, iPhone, and iPad. Since it is not easy for students to post messages using a text-based input, asynchronous voice discussion via built-in microphones on mobile devices may be a viable alternative.

\section{References}

Akasha, O. (2011). Voicethread as a Good Tool to Motivate ELLs and Much More. In M. Koehler \& P. Mishra (Eds.), Proceedings of Society for Information Technology \& Teacher Education International Conference 2011 (pp. 3123-3127). Virginia, NV: Association for the Advancement of Computing in Education.

Allen, I. E., \& Seaman, J. (2013). Changing course. Ten years of tracking online education in the United States. LLC: Babson Survey Research Group and Quahog Research Group.

Bowe, F. G. (2002). Deaf and hard of hearing Americans' instant messaging and e-mail use: A national survey. American Annals of the Deaf, 147(4), 6-10.

Brunvand, S., \& Byrd, S. (2011). Using voice thread to promote learning engagement and success for all students. Teaching Exceptional Children, 43(4), 28-37.

Chang, C.-K. (2010). Acceptability of an asynchronous learning forum on mobile devices. Behavior and Information Technology, 29(1), 22-33.

Cheung, W. S., \& Hew, K. F. (2006). Examining students' creative and critical thinking and student to student interactions in an asynchronous online discussion environment: A Singapore case study. Asia-Pacific Cybereducation Journal, 2(2), 1-11. 
Cheung, W. S., \& Hew, K. F. (2011). Design and evaluation of two blended learning approaches: Lessons learned. Australasian Journal of Educational Technology, 27(8), 1319-1337.

Cho, S. P., \& Carey, S. (2001). Increasing Korean oral fluency using an electronic bulletin board and Wimba-based voiced chat. The Korean Language in America, 6, 115-128.

Dunlap, J. C. (2005). Workload reduction in online courses: Getting some shuteye. Performance and Improvement, 44(5), 18-25.

Durbridge, N. (1984). Media in course design, No. 9, audio cassettes. The role of technology in distance education. Kent: Croom Helm.

Dysthe, O. (2002). The learning potential of a web-mediated discussion in a university course. Studies in Higher Education, 27(3), 339-352.

Dziuban, C. D., Hartman, J. L., \& Moskal, P. D. (2004). Blended learning. Educause Center for Applied Research (ECAR) Research Bulletin, 7. Retrieved February 16, 2012 from http://net.educause.edu/ ir/library/pdf/ERB0407.pdf.

Ertmer, P. A., Richardson, J. C., Belland, B., Camin, D., Connolly, P., Coulthard, G., Lei, K. \& Mong, C. (2007). Using peer feedback to enhance the quality of student online postings: An exploratory study. Journal of Computer Mediated Communication, 12(2), 412-433. Retrieved January 20, 2012 from http://jcmc.indiana.edu/vol12/issue2/ertmer.html.

Gleason, J., \& Suvorov, R. (2011). Learner perceptions of asynchronous oral computer-mediated communication tasks using Wimba Voice for developing their L2 oral proficiency. In S. Huffman \& V. Hegelheimer (Eds.), The role of CALL in hybrid and online language courses. Ames, IA: Iowa State University.

Greenlaw, S. A., \& DeLoach, S. B. (2003). Teaching critical thinking with electronic discussion. The Journal of Economic Education, 34(1), 36-52.

Henri, F. (1992). Computer conferencing and content analysis. In A. R. Kaye (Ed.), Collaborative learning through computer conferencing: The Najaden papers (pp. 117-136). Berlin: Springer.

Hew, K. F., \& Cheung, W. S. (2012). Student participation in online discussions: Challenges, solutions, and future research. New York, NY: Springer.

Hew, K. F., \& Cheung, W. S. (2013). Audio-based versus text-based asynchronous online discussion: Two case studies. Instructional Science, 41(2), 365-380. doi:10.1007/s11251-012-9232-7.

Hew, K. F., \& Hara, N. (2007). Empirical Study of Motivators and Barriers of Teacher Online Knowledge Sharing. Educational Technology Research and Development, 55(6), 573-595.

Hew, K. F., Liu, S., Martinez, R., Bonk, C., \& Lee, J. Y. (2004). Online education evaluation: What should we evaluate? The Proceedings of the Association for Educational Communications and Technology (pp. 243-246). Chicago, IL: Association for Educational Communications and Technology.

Junor, L. (1992). Teaching by tape: Some benefits, problems, and solutions. Distance Education, 13(1), 93-107.

Kalelioglu, F., \& Gulbahar, Y. (2014). The effect of instructional techniques on critical thinking and critical thinking dispositions in online discussion. Educational Technology \& Society, 17(1), 248-258.

Lee, S. W.-Y. (2013). Investigating students' learning approaches, perceptions of online discussions, and students' online and academic performance. Computers \& Education, 68, 345-352.

Loncar, M., Barrett, N. E., \& Liu, G.-Z. (2014). Towards the refinement of forum and asynchronous online discussion in educational contexts worldwide: Trends and investigative approaches within a dominant research paradigm. Computers \& Education, 73, 93-110.

Mandernach, B. J., \& Taylor, S. S. (2011). Web 2.0 applications to foster student engagement. In R. L. Miller, et al. (Eds.), Promoting student engagement. Volume 1: Programs, techniques and opportunities (pp. 220-229). Washington, DC: Society for the teaching of psychology: Division 2, American Psychological Association.

Marriott, P., \& Hiscock, J. (2002). Voice vs text-based discussion forums: An implementation of Wimba Voice Boards. In M. Driscoll \& T. Reeves (Eds.), Proceedings of World Conference on E-Learning in Corporate, Government, Healthcare, and Higher Education 2002 (pp. 640-646). Virginia, NV: Association for the Advancement of Computing in Education.

Maurer, M. (2011). Blackboard mobile apps reach nearly three million downloads. Retrieved November 14, 2011 from http://www.blackboard.com/About-Bb/Media-Center/Press-Releases.aspx?releaseid= 1618480 .

McCormack, V. (2010). Increasing teacher candidate responses through the application of VoiceThread. International Journal of Arts and Sciences, 3(11), 160-165. 
McIntosh, S., Braul, B., \& Chao, T. (2003). A case study in asynchronous voice conferencing for language instruction. Educational Media International, 40(1), 63-74.

Merriam, S. B. (2001). Qualitative research and case study applications in education. San Francisco, CA: Jossey-Bass.

Nowakowski, R. W., \& Frazier, M. (2009). Wimba Voice for teaching "Spanish for eye care" in a blended course environment. Optometric Education, 34(3), 97-103.

Poscente, K. R., \& Fahy, P. J. (2003). Investigating triggers in CMC text transcripts. The International Review of Research in Open and Distance Learning, 4(2). Retrieved January 25, 2013 from http:// www.irrodl.org/index.php/irrodl/article/view/141/221.

Poza, M. S. C. (2011). The effects of asynchronous computer voice conferencing on L2 learners' speaking anxiety. IALLT Journal of Language Learning Technologies, 41(1), 33-63.

Richardson, J. C., \& Swan, K. (2003). Examining social presence in online courses in relation to students' perceived learning and satisfaction. Journal of Asynchronous Learning Networks, 7(1), 68-88.

Thomas, J. (2013). Exploring the use of asynchronous online discussion in health care education: A literature review. Computers \& Education, 69, 199-215.

Yaneske, E., \& Oates, B. (2010). Using Voice Boards: Pedagogical design, technological implementation, evaluation and reflections. ALT-J Research in Learning Technology, 18(3), 233-250.
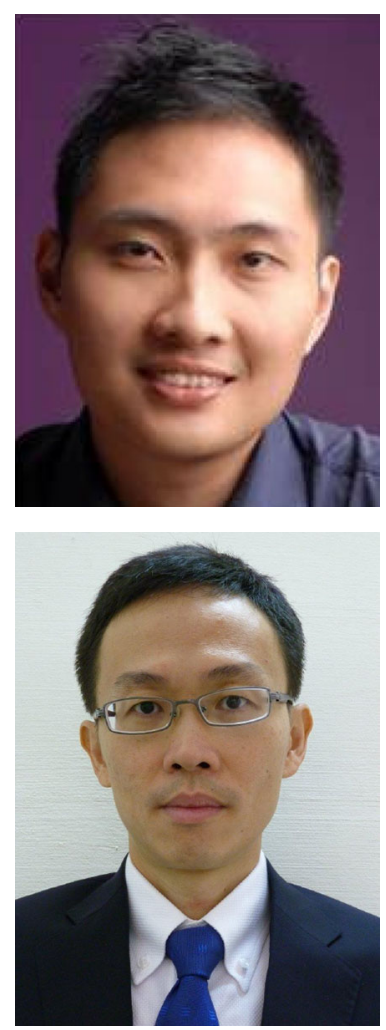

Biao Bin Pang is an education officer with the Ministry of Education in Singapore. He is currently teaching music in Huamin Primary School. He has a master degree in Learning Sciences and Technology. His research interest focuses on examining how the use of information and communication technology can enhance teaching and learning.

Khe Foon Hew is with the division of Information and Technology Studies, Faculty of Education at the University of Hong Kong. He earned his $\mathrm{PhD}$ from Indiana University, USA. His research primarily focuses on three major areas: instructional strategy, instructional technology, and social interaction theory. He serves on numerous editorial/review boards such as the British Journal of Educational Technology, and the Educational Technology Research \& Development (ETR\&D). 